\title{
HUBUNGAN ANTARA OBESITAS DAN AKTIVITAS FISIK DENGAN KEJADIAN HIPERTENSI DI PUSKESMAS RAWASARI KOTA JAMBI TAHUN 2018
}

\section{Correlation Between Obesity and Physical Activity With Hypertension Incidence of Rawasari Public Health Center in Jambi City 2018}

\author{
Sintya Dwi Anggraini ${ }^{1}$, M Dody Izhar $^{2}$, Dwi Noerjoedianto ${ }^{2}$ \\ ${ }^{1}$ Program Sarjana Studi Ilmu Kesehatan Masyarakat Universitas Jambi \\ ${ }^{2}$ Ilmu Kesehatan Masyarakat, Fakultas Kesehatan Masyarakat, Universitas Jambi
}

\begin{abstract}
Abstrak
Hipertensi yang juga dikenal sebagai tekanan darah tinggi, merupakan kondisi pembuluh darah yang terusmenerus menaikkan tekanan di atas normal. Secara global, penyakit kardiovaskular menyumbang sekitar 17 juta kematian per tahunnya, hampir sepertiga dari total. Dari jumlah tersebut, komplikasi hipertensi menyumbang 9,4 juta kematian di seluruh dunia setiap tahunnya. Hipertensi adalah salah satu penyebab kematian dini di seluruh dunia dan masalah ini semakin berkembang. Pada tahun 2025, diperkirakan 1,56 miliar orang dewasa akan hidup dengan hipertensi. Terdapat beberapa faktor risiko yang memiliki peran dalam terjadinya hipertensi, termasuk obesitas dan rendahnya aktivitas fisik. Penelitian ini dilakukan di Puskesmas Rawasari Jambi pada bulan April Mei 2018. Penelitian ini merupakan penelitian analitik observasional dengan menggunakan pendekatan cross sectional. Pengambilan sampel menggunakan teknik nonprobability sampling dengan jumlah sampel 97 responden. Data diperoleh dengan menggunakan wawancara, pengukuran tekanan darah, dan pengukuran tinggi dan berat badan. Data dianalisis menggunakan uji chi-square. Hasil peneltian menunjukkan bahwa dari 97 responden, $41.24 \%$ berusia 60 - 69 tahun, 51,55\% responden adalah laki-laki, 44,33\% responden tamat SMA/MA, $38,14 \%$ responden adalah ibu rumah tangga, 53,61\% responden mengalami obesitas, 43,40\% responden memiliki aktivitas fisik ringan, dan 62,89\% memiliki tekanan darah tinggi atau hipertensi. Terdapat hubungan antara obestas dengan hipertensi $(\mathrm{p}=0,004)$, dan terdapat hubungan antara aktivitas fisik dengan hipertensi $(\mathrm{p}=0,000)$. Tekanan darah tinggi dapat dicegah dengan mengadopsi modifikasi gaya hidup sesuai dengan rekomendasi JNC VII.
\end{abstract}

Kata kunci: Hipertensi, Obesitas, Aktivitas Fisik

\begin{abstract}
Hypertension, also known as high or raised blood pressure, is a condition in which the blood vessels have persistently raised pressure. Globally cardiovascular disease counts for approximately 17 million deaths a year, nearly one third of the total. Of these, complications of hypertension account for 9.4 million deaths worldwide every year. Hypertension is one of the most important causes of premature death worldwide and the problem is growing; in 2025, an estimated 1.56 billion adults will be living with hypertension. There are a few risk factors suspected to have a role in hypertension, including obesity and low physical activity. This study was conducted in Puskesmas Rawasari Jambi from April-May 2018. This is an observational analytical study with cross-sectional approach. Samples were chosen using non-probability sampling technique followed by 97 respondents. The data was gained using interview, blood pressure measurement, and height and weight measurements. The data was analyzed using chi-square test. Results showed that of all 97 samples, $41.24 \%$ were 60 - 69 years old, 51.55\% were male, $44.33 \%$ finished high school, $38.14 \%$ were housewife, $53.61 \%$ were obese, $43.40 \%$ had low physical activity, and $62.89 \%$ had high blood pressure or hypertension. There was a correlation between obese and hypertension $(\mathrm{p}=0.004)$, and there was correlation between physical activity and hypertension $(\mathrm{p}=0.000)$. High blood pressure is largely preventable by adopting lifestyle modifications by JNC VII.
\end{abstract}

Keywords: Hypertension, Obese, Physical activity

Korespondensi: Sintya Dwi Anggraini

Email: sintyasda@yahoo.com 


\section{PENDAHULUAN}

Perubahan struktur masyarakat seperti struktur kependudukan, gaya hidup, sosial ekonomi, lingkungan dan teknologi memicu terjadinya transisi epidemiologi yang mengakibatkan perubahan pola penyakit menular ke penyakit degenaratif atau penyakit tidak menular ${ }^{1,2}$. Penyakit tidak menular atau noncommunicable diseases (NCDs) membunuh 40 juta orang setiap tahunnya atau setara dengan $70 \%$ kematian di seluruh dunia ${ }^{3}$. Hipertensi atau tekanan darah tinggi adalah salah satu penyakit tidak menular yang paling banyak dijumpai, dimana merupakan kondisi pembuluh darah yang terus-menerus menaikkan tekanan di atas normal ${ }^{4}$. Hipertensi adalah faktor risiko utama penyakit kardiovaskular yang menjadi penyebab utama kematian global yang menewaskan 17,7 juta orang per tahunnya 5 . Prevalensi hipertensi terus meningkat di seluruh dunia dari $25 \%$ di tahun 2000 sampai diproyeksikan menjadi $40 \%$ pada tahun $2025^{4}$. Hipertensi juga menyebabkan $45 \%$ beban penyakit secara global ${ }^{6}$.

Sebesar $90 \%$ atau lebih penderita hipertensi yang ada adalah penderita hipertensi esensial/primer ${ }^{6}$. Faktor genetik dan lingkungan memegang peranan penting pada patogenesis hipertensi esensial ${ }^{2}$. Hipertensi esensial terjadi dikarenakan dua faktor, yaitu faktor yang tidak dapat diubah dan faktor risiko yang dapat diubah. Faktor risiko yang tidak dapat diubah antara lain, riwayat keluarga atau keturunan, umur, dan jenis kelamin. Sedangkan faktor risiko yang dapat diubah seperti obesitas, aktivitas fisik yang tidak terpenuhi, stres, pola konsumsi tidak sehat, merokok, meminum minuman beralkohol, dan sebagainya ${ }^{6}$.

Semakin bertambahnya umur seseorang semakin tinggi pula prevalensi seseorang terkena hipertensi. (Kemenkes RI, 2013). Setelah usia 45 tahun terjadi peningkatan resistensi perifer dan aktivitas simpatik serta kurangnya sensitivitas baroreseptor (pengatur tekanan darah) ${ }^{7}$. Dari beberapa faktor risiko hipertensi, obesitas/kegemukan memiliki kaitan yang erat terhadapnya. Kegemukan dan tekanan darah adalah pasangan yang seiring sejalan. Semakin gemuk seseorang, semakin tinggi pula tekanan darahnya $^{8}$. Hal ini sejalan dengan penelitian Sulastri dkk (2012) yang menunjukkan hasil obesitas merupakan faktor risiko terjadinya hipertensi, dimana responden yang mengalami obesitas berisiko untuk hipertensi 1,82 kali jika dibandingkan dengan responden yang tidak obesitas 9 .

Ketika tren penyakit bergeser kearah noncommunicable diseases, bahasan tentang olahraga dan takaran aktivitas fisik perlu menjadi prioritas penting bagi tiap orang ${ }^{8}$. Aktivitas fisik yang tidak tercukupi merupakan faktor risiko utama noncommunicable diseases. Sebesar 1,6 juta kematian per tahun disebabkan oleh aktivitas fisik yang tidak tercukupi. Aktivitas fisik diperkirakan menjadi penyebab utama sebesar $30 \%$ beban penyakit kardiovaskular seperti hipertensi. Hal ini sejalan dengan hasil penelitian Atun dkk (2014) yang menunjukkan ada hubungan yang bermakna antara aktivitas fisik dengan tekanan darah, subyek dengan aktivitas fisik kurang mempunyai risiko 4.9 kali terkena hipertensi dibandingkan dengan subyek yang memiliki aktivitas fisik sedang. Seseorang dengan aktivitas fisik kurang, memiliki kecenderungan $30-50 \%$ terkena hipertensi daripada mereka yang aktif. Peningkatan intensitas aktivitas fisik, 30 - 45 menit per hari, penting dilakukan sebagai strategi untuk pencegahan dan pengelolaan hipertensi ${ }^{10}$.

Berdasarkan hasil survey Riset Kesehatan Dasar pada tahun 2013, Indonesia memiliki prevalensi hipertensi sebesar 26,5\% dan Provinsi Jambi memiliki prevalensi hipertensi sebesar $24,6 \%$, disebutkan dalam survey bahwa prevalensi hipertensi di perkotaan lebih tinggi dibandingkan di perdesaan ${ }^{11}$. Ini dialami juga oleh Provinsi Jambi, Kota Jambi memiliki jumlah kasus hipertensi tertinggi yaitu sebanyak 26.627 kasus, diikuti oleh Muaro Jambi dengan 10.911 
kasus $^{12}$. Data tahun 2016 menunjukkan bahwa prevalensi hipertensi di Kota Jambi mencapai 36\%. Untuk hipertensi esensial di Kota Jambi menempati urutan kedua setelah nasopharingitis akut pada 10 penyakit terbesar di Kota Jambi dengan jumlah kasus sebesar 36.649 dan persentase $10,30 \%{ }^{13}$.

Diantara 20 puskesmas di Kota Jambi, Puskesmas Rawasari memiliki jumlah kasus hipertensi terbanyak dibandingkan Puskesmas lain degan jumlah kasus 4846 kasus di tahun 2016. Selain itu, Puskesmas Rawasari juga berada dalam 5 besar puskesmas yang memiliki prevalensi hipertensi esensial tertinggi pada tahun 2016 dengan 8,81\%. Puskesmas Rawasari juga mengalami peningkatan prevalensi yang paling signifikan yaitu sebesar $5,15 \%$ dari $3,67 \%$ di tahun 2015 menjadi 8,81\% di tahun 2016. Ini menjadikan Puskesmas Rawasari berada di peringkat 1 untuk peningkatan prevalensi di bandingkan puskesmas lain di Kota Jambi.

Berdasarkan uraian diatas maka, peneliti tertarik untuk melakukan penelitian dengan judul "Hubungan Antara Obesitas dan Aktivitas Fisik Dengan Kejadian Hipertensi di Puskesmas Rawasari Kota Jambi Tahun 2018”.

\section{METODE}

Penelitian ini menggunakan jenis penelitian observasional analitik dengan rancangan cross sectional atau potong lintang yaitu menghubungkan antara faktor - faktor risiko variabel independen dan dependen secara bersama-sama atau sekaligus, tiap subjek penelitian hanya diobservasi satu kali, tidak ada follow up.

Penelitian dilaksanakan pada bulan April Mei 2018 di Puskesmas Rawasari Kota Jambi. Subjek penelitian dipilih dengan metode consecutive sampling.
Jumlah subjek penelitian sebanyak 97 orang diambil berdasarkan kriteria inklusi dan ekslusi. Adapun kriteria inklusi penelitian antara lain, masyarakat di wilayah kerja Puskesmas Rawasari yang berkunjung ke puskemas pada saat penelitian berlangsung, berumur $\geq 45$ tahun, dapat berkomunikasi dengan baik, dan bersedia menjadi responden. Sedangkan kriteria ekslusi penelitian adalah wanita hamil dan penderita hipertensi sekunder dengan terdiagnosis komplikasi hipertensi.

Intrumen yang digunakan dalam penelitian ini antara lain, tensimeter untuk mengukur tekanan darah, timbangan injak untuk mengukur berat badan, microtoise untuk mengukur tinggi badan, serta kuesioner GPAQ-WHO yang berisi 16 pertanyaan untuk mengukur aktivitas fisik responden. Analisis data yang dilakukan yaitu analisis data univariat dan analisis data bivariat dengan menggunakan uji chi square $(\alpha=0,05$; $\mathrm{CI}=95 \%)$.

\section{HASIL DAN PEMBAHASAN HASIL}

Tabel 1 menunjukkan hasil univariat karakteristik responden yang mendeskripsikan atau menggambarkan meliputi usia, jenis kelamin, pendidikan, dan pekerjaan responden di Puskesmas Rawasari Tahun 2018. Hasil univariat karakteristik responden menunjukkan bahwa sebanyak 40 orang $(41,24 \%)$ paling banyak berusia $60-69$ tahun, responden yang paling banyak adalah laki-laki yaitu sebanyak 50 orang $(51,55 \%)$, yang paling banyak responden dengan tamat SMA/MA sebanyak 43 orang $(44,33 \%)$, dan responden memiliki pekerjaan paling banyak sebagai ibu rumah tangga sebanyak 37 orang $(38,14 \%)$. 
Tabel 1. Distibusi Frekuensi Berdasarkan Karakteristik Responden di Puskesmas Rawasari Kota Jambi Tahun 2018

\begin{tabular}{llcc}
\hline \multirow{2}{*}{ Karakteristik Responden } & \multicolumn{1}{c}{ Kategori } & $\begin{array}{c}\text { Frekuensi } \\
(\mathbf{n})\end{array}$ & $\begin{array}{c}\text { Persentasi } \\
(\mathbf{\%})\end{array}$ \\
\hline \multirow{4}{*}{ Usia } & $45-49$ & 17 & 17,52 \\
& $50-59$ & 31 & 31,96 \\
\multirow{2}{*}{ Jenis Kelamin } & $60-69$ & 40 & 41,24 \\
& $\geq 70$ & 9 & 9,28 \\
\hline \multirow{5}{*}{ Pendidikan } & Laki-laki & 50 & 51,55 \\
& Perempuan & 47 & 48,45 \\
\hline \multirow{5}{*}{ Pekerjaan } & Tamat SD/MI & 14 & 14,43 \\
& Tamat SMP/MTs & 10 & 10,31 \\
& Tamat SMA/MA & 43 & 44,33 \\
& Tamat D1-D3/PT & 30 & 30,93 \\
\hline & Tidak Bekerja & 3 & 3,10 \\
& PNS/TNI/Polri/BUMN/BUMD & 12 & 12,37 \\
& Pegawai swasta & 6 & 6,18 \\
& Wiraswasta & 12 & 12,37 \\
& Buruh & 3 & 3,10 \\
& IRT & 37 & 38,14 \\
& Pensiunan & 24 & 24,74 \\
\hline
\end{tabular}

Tabel 2 menunjukkan hasil univariat variabel penelitian. Adapun hasil univariat variabel penelitian meliputi gambaran obesitas, aktivitas fisik, dan kejadian hipertensi. Gambaran obesitas menunjukkan bahwa sebanyak 52 $(53,61 \%)$ orang mengalami obesitas dan sebanyak 45 orang $(46,39 \%)$ tidak obesitas. Gambaran aktivitas fisik responden menunjukkan bahwa sebanyak 42 orang
(43,30\%) memiliki aktivitas fisik dengan intensitas ringan, sebanyak 40 orang $(41,24 \%)$ memiliki aktivitas fisik dengan intensitas sedang, dan sebanyak 15 orang $(15,46 \%)$ memiliki aktivitas fisik dengan intensitas tinggi. Dan gambaran kejadian hipertensi responden menunjukkan bahwa sebanyak 61 orang $(62,89 \%)$ mengalami hipertensi dan sebanyak 36 orang $(37,11 \%)$ tidak hipertensi.

Tabel 2. Distibusi Frekuensi Berdasarkan Variabel Penelitian di Puskesmas Rawasari Kota Jambi Tahun 2018

\begin{tabular}{|c|c|c|c|}
\hline Variabel Penelitian & Kategori & $\begin{array}{c}\text { Frekuensi } \\
\text { (n) }\end{array}$ & $\begin{array}{c}\text { Persentasi } \\
(\%)\end{array}$ \\
\hline \multirow{2}{*}{ Obesitas } & $\mathrm{Ya}$ & 52 & 53,61 \\
\hline & Tidak & 45 & 46,39 \\
\hline \multirow{3}{*}{ Aktivitas Fisik } & Ringan & 42 & 43,30 \\
\hline & Sedang & 40 & 41,24 \\
\hline & Tinggi & 15 & 15,46 \\
\hline \multirow{3}{*}{ Hipertensi } & $\mathrm{Ya}$ & 61 & 62,89 \\
\hline & Tidak & 36 & 37,11 \\
\hline & Total & 97 & 100 \\
\hline
\end{tabular}

Pada tabel 3 disajikan analisis bivariat yang dilakukan untuk mengetahui hubungan antara variabel dependen (kejadian hipertensi) dan variabel independen (obesitas dan aktivitas fisik). Hasil analisis ini dilakukan dengan tabulasi silang menggunakan uji chi square dengan tingkat kepercayaan $\alpha=0,05$.

Hasil analisis menunjukkan bahwa dari 52 orang yang obesitas, sebanyak 40 orang $(76,92 \%)$ diantaranya mengalami hipertensi dan dari 45 orang yang tidak obesitas, sebanyak 21 orang 
(46,67\%) diantaranya juga mengalami hipertensi. Didapatkan nilai $p$ value sebesar 0,004 ( $p$ value $<\alpha$ ) yang berarti Ha gagal ditolak, dapat disimpulkan terdapat hubungan yang signifikan antara obesitas dengan kejadian hipertensi di Puskesmas Rawasari Kota Jambi Tahun 2018.

Kemudian, dari 42 orang yang memiliki aktivitas fisik dengan intensitas ringan, sebanyak 37 orang $(88,10 \%)$ diantaranya mengalami hipertensi; dari 40 orang yang memiliki aktivitas fisik dengan intensitas sedang, sebanyak 19 orang $(47,50 \%)$ diantaranya mengalami hipertensi; dan dari 15 orang yang memiliki aktivitas fisik dengan intensitas tinggi, sebanyak 5 orang $(3,33 \%)$ diantaranya mengalami hipertensi. Didapatkan nilai $p$ value sebesar 0,000 ( $p$ value $<\alpha$ ) yang berarti Ha gagal ditolak, dengan kata lain terdapat hubungan yang signifikan antara aktivitas fisik dengan kejadian hipertensi di Puskesmas Rawasari Kota Jambi Tahun 2018.

Tabel 3. Hubunngan Obesitas dan Aktivitas Fisik dengan Kejadian Hipertensi di Puskesmas Rawasari Kota Jambi Tahun 2018

\begin{tabular}{|c|c|c|c|c|c|c|c|c|}
\hline \multirow{3}{*}{ Variabel } & \multirow{3}{*}{ Kategori } & \multicolumn{4}{|c|}{ Kejadian Hipertensi } & \multirow{2}{*}{\multicolumn{2}{|c|}{ Total }} & \multirow{3}{*}{ P value } \\
\hline & & \multicolumn{2}{|c|}{ HT } & \multicolumn{2}{|c|}{ Tidak HT } & & & \\
\hline & & $\mathbf{n}$ & $\%$ & $\mathbf{n}$ & $\%$ & $\mathbf{n}$ & $\%$ & \\
\hline \multirow{2}{*}{ Obesitas } & $\mathrm{Ya}$ & 40 & 76,92 & 12 & 23,08 & 52 & 100 & \multirow{2}{*}{0,004} \\
\hline & Tidak & 21 & 46,67 & 24 & 53,33 & 45 & 100 & \\
\hline \multirow{3}{*}{ Aktivitas Fisik } & Ringan & 37 & 88,10 & 5 & 11,90 & 42 & 100 & \multirow{3}{*}{0,000} \\
\hline & Sedang & 19 & 47,50 & 21 & 52,50 & 40 & 100 & \\
\hline & Tinggi & 5 & 33,33 & 10 & 66,67 & 15 & 100 & \\
\hline
\end{tabular}




\section{PEMBAHASAN}

\section{Hubungan Obesitas dengan Kejadian Hipertensi}

Hasil univariat menunjukkan responden yang memiliki obesitas yaitu sebanyak 52 orang $(53,61 \%)$ dan responden yang tidak obesitas yaitu sebanyak 45 orang $(46,39 \%)$. Dari hasil analisis bivariat diperoleh nilai $p$ value $=0,004$ dengan nilai $\alpha=0,05$ ( $p$ value $<\alpha$ ), ini berarti ha gagal ditolak yang dapat disimpulkan terdapat hubungan yang signifikan antara obesitas dengan kejadian hipertensi di Puskesmas Rawasari Kota Jambi Tahun 2018.

Pada prinsipnya, obesitas adalah ketidakseimbangan antara masukan energi dan energi yang dikeluarkan, dimana masukan energi lebih besar dibandingkan energi yang dikeluarkan ${ }^{14}$. Pada orang yang obesitas terjadi peningkatan kerja pada jantung untuk memompa darah. Berat badan berlebihan menyebabkan bertambahnya volume darah dan perluasan sistem sirkulasi. Makin besar massa tubuh, makin banyak pula suplai darah yang dibutuhkan untuk memasok oksigen dan nutrisi ke jaringan tubuh. Hal ini mengakibatkan volume darah yang beredar melalui pembuluh darah akan meningkat sehingga tekanan pada dinding arteri menjadi lebih besar ${ }^{15}$.

Pada obesitas, tahanan perifer berkurang sedangkan saraf simpatis meninggi dengan aktifitas renin plasma yang rendah. Makin besar massa tubuh, makin banyak darah yang dibutuhkan untuk memasok oksigen dan makanan ke jaringan tubuh. Kondisi obesitas berhubungan dengan peningkatan volume intravaskuler dan curah jantung. Daya pompa jantung dan sirkulasi volume darah penderita hipertensi lebih tinggi dibandingkan dengan penderita hipertensi dengan berat badan normal 16 .

Hal ini sejalan dengan penelitian yang dilakukan oleh Anggara dan Prayitno (2013) di Puskesmas Telaga Murni Cikarang yang menunjukkan ada hubungan bermakna antara
IMT (obesitas) dengan kejadian hipertensi ( $p=$ $0.000)^{17}$. Penelitian yang dilakukan oleh Rohkuswara dan Syarif (2017) di Posbindu KKP Bandung juga mengemukakan bahwa obesitas merupakan faktor risiko kejadian hipertensi dengan nilai $\mathrm{PR}=2,008$ dan $95 \% \mathrm{CI}=1,379$ 2,925. Hal tersebut berarti bahwa obesitas memiliki risiko hipertensi sebesar 2 kali dibandingkan orang yang tidak obesitas ${ }^{16}$.

Penelitian yang dilakukan Hasanah dkk (2016) pada masyarakat RW 13 di Karangploso juga mendukung pernyataan bahwa obesitas memiliki hubungan dengan terjadinya hipertensi $(\mathrm{p}=0,000<0,05)$. Ini disebabkan oleh kebanyakan masyarakat tidak sadar akan pentingnya melakukan aktivitas fisik seperti olahraga dalam menjaga berat badan, ditambah lagi dengan pola makan dan gaya hidup masyarakat yang buruk. Ini terbukti dari hasil penelitian yang menujukkan sebanyak $75,8 \%$ masyarakat tidak suka berolahraga ${ }^{18}$.

Peneliti menyimpulkan salah satu penyebab banyaknya responden yang mengalami obesitas dalam penelitian ini adalah kurangnya aktivitas fisik. Ini dibuktikan, sebanyak 33 $(63,46 \%)$ orang obesitas memiliki aktivitas fisik dengan intensitas ringan. Hal mendasar terjadinya obesitas adalah tubuh menerima lebih banyak kalori daripada membakar kalori, kalori berlebih tersebut akan menumpuk dan menjadi lemak. Perlu keseimbangan antara masukan energi dan energi yang dikeluarkan, karenanya tingkat aktivitas dan olahraga memiliki peran dalam pengeluaran energi sehingga kurangnya aktivitas fisik/olahraga memiliki pengaruh akan terjadinya obesitas ${ }^{14}$.

Selain itu, faktor usia juga mempengaruhi untuk terjadinya obesitas. Obesitas berkaitan dengan usia, karena semakin usia bertambah maka metabolisme yang terjadi didalam tubuh mengalami penurunan yang akan terjadi perubahan secara biologis yaitu menurunnya fungsi dari otot-otot dan meningkatnya kadar lemak dalam tubuh ${ }^{19}$. Pernyataan ini didukung 
oleh hasil penelitian yang menunjukkan semakin bertambahnya umur semakin besar responden menderita obesitas. Sebanyak 8 (15,38\%) orang obesitas berusia 45 - 49 tahun, sebanyak 13 (25\%) orang obesitas berusia 50 - 59 tahun, dan sebanyak $31(59,62 \%)$ orang obesitas berusia di atas 60 tahun.

Semakin tua usia seseorang, kurang aktif bergerak menyebabkan massa otot dalam tubuh cenderung menurun yang menyebabkan perlambatan tingkat pembakaran kalori dalam tubuh. Semakin bertambah usia dan dengan asupan kalori yang tetap, tubuh semakin sulit untuk membakar kalori yang masuk sehingga terjadi penumpukan energi didalam tubuh dan berdampak pada obesitas ${ }^{20}$.

Sebenarnya di antara semua faktor risiko hipertensi yang dapat dikendalikan, berat badan adalah salah satu yang paling erat kaitannya dengan hipertensi. Kegemukan merupakan ciri khas dari populasi hipertensi. Penyelidikan epidemiologi membuktikan bahwa obesitas merupakan ciri khas pada populasi pasien hipertensi. Di perkirakan sebanyak $70 \%$ kasus baru penyakit hipertensi adalah orang dewasa yang berat badannya sedang bertambah. ${ }^{21,22}$.

Menerapkan gaya hidup sehat bagi setiap orang sangat penting untuk mencegah tekanan darah tinggi dan merupakan bagian yang penting dalam penanganan hipertensi. Memodifikasi gaya hidup dapat menurunkan tekanan darah sesuai dengan rekomendasi dari JNC VII, yaitu menurunkan berat badan hingga tercapai nilai IMT normal (18,5 - 24,9); mengadopsi pola makan DASH (Dietary Approach to Stop Hypertension) diet kaya dengan buah, sayur, dan rendah lemak; diet rendah sodium $(\leq 2,4$ gram natrium atau 6 gram $\mathrm{NaCl}$ ); melakukan aktivitas fisik aerobik seperti jalan kaki 30 menit/hari; dan mengurangi konsumsi alkohol ${ }^{6}$.

Diantara modifikasi gaya hidup yang dapat dilakukan sesuai dengan rekomendasi dari JNC VII, menurunkan berat badan hingga tercapai nilai IMT normal $(18,5$ - 24,9) adalah yang paling banyak menurunkan tekanan darah yaitu sebesar 5 - $20 \mathrm{mmHg}$. Bisa diartikan bahwa penurunan berat badan adalah perubahan gaya hidup yang paling besar pengaruhnya terhadap perbaikan tekanan darah ${ }^{6,8}$.

\section{Hubungan Aktivitas Fisik dengan Kejadian Hipertensi}

Berdasarkan hasil penelitian diperoleh bahwa dari 42 responden yang memiliki aktivitas fisik ringan, sebanyak 37 orang $(88,10 \%)$ diantaranya mengalami hipertensi. Sedangkan diantara 40 responden yang mempunyai aktivitas fisik sedang, ada sebanyak 19 orang $(47,50 \%)$ yang mengalami hipertensi. Dan dari 15 responden dengan aktivitas fisik tinggi, sebanyak 5 orang $(33,33 \%)$ mengalami hipertensi. Hasil uji statistik diperoleh nilai $p=0,000$ mempunyai arti bahwa $p<0,05$ maka hipotesis gagal ditolak dengan kata lain terdapat hubungan antara aktivitas fisik dengan kejadian hipertensi di Puskesmas Rawasari Kota Jambi Tahun 2018.

Aktivitas fisik adalah gerakan tubuh yang dihasilkan oleh otot rangka yang memerlukan pengeluaran energi termasuk aktivitas yang dilakukan saat bekerja, bermain, melakukan pekerjaan rumah, bepergian, dan kegiatan rekreasi ${ }^{23}$. Aktivitas fisik yang dilakukan secara teratur dapat mengurangi kekakuan pembuluh darah dan meningkatkan daya tahan jantung serta paru-paru sehingga dapat menurunkan tekanan darah $^{6}$.

Kegiatan fisik yang dilakukan secara teratur menyebabkan jantung akan bertambah kuat pada otot polosnya sehingga daya tampung besar dan kontraksi atau denyutannya kuat dan teratur, selain itu elastisitas pembuluh darah akan bertambah karena adanya relaksasi dan kontraksi otot dinding pembuluh darah. Kondisi tekanan darah yang tinggi menambah beban jantung dan arteri. Jantung harus bekerja lebih keras dari normal. Pembuluh darah menerima aliran darah yang bertekanan lebih tinggi dari biasanya. Keadaan aliran darah yang kurang lancar juga 
bagian dari masalah kesehatan rata-rata orang modern. Kurang gerak yang menjadikan daya pompa kantung kurang optimal sehingga aliran darah dalam tubuh tidak deras dan tidak lancar ${ }^{15}$.

Hal ini sejalan dengan penelitian yang dilakukan oleh Hengli (2013) di wilayah kerja Puskesmas Siantan Hulu yang menunjukkan terdapat hubungan antara aktivitas fisik dengan kejadian hipertensi dengan nilai $\mathrm{p}=0,000<0,05$. Ini disebabkan oleh kuranngnya kesadaran masyarakat untuk melakukan olahraga. Masyarakat beranggapan bahwa pekerjaan mereka sudah termasuk olahraga, sehingga responden yang tidak beraktivitas fisik atau aktivitas fisiknya tidak ideal lebih banyak (56\%) dibandingkan yang aktivitas fisik ${ }^{24}$.

Penelitian yang diakukan oleh Muliyati dkk (2011) juga menunjukkan hasil bahwa terdapat hubungan yang signifikan antara aktivitas fisik dengan kejadian hipertensi ( $p$ value $=0,018<0,05)^{25}$. Serta, penelitian yang dilakukan oleh Atun dkk (2014) juga menunjukkan ada hubungan yang bermakna antara aktivitas fisik dengan tekanan darah, subyek dengan aktivitas fisik kurang mempunyai risiko 4.9 kali terkena hipertensi dibandingkan dengan subyek yang memiliki aktivitas fisik sedang. Seseorang dengan aktivitas fisik kurang, memiliki kecenderungan $30-50 \%$ terkena hipertensi daripada mereka yang aktif ${ }^{10}$.

Terdapatnya hubungan antara aktivitas fisik dengan kejadian hipertensi pada penelitian ini dikarenakan sebagian besar subyek penelitian memiliki aktivitas fisik dengan intensitas ringan. Dari 42 orang dengan aktivitas ringan, sebanyak $37(88,10 \%)$ orang mengalami hipertensi. Kurangnya aktivitas fisik menyebabkan jantung tidak terlatih, pembuluh darah kaku, dan sirkulasi darah tidak lancar ${ }^{26}$.

Selain itu, kurangnya aktifitas fisik meningkatkan risiko menderita hipertensi karena meningkatkan risiko kelebihan berat badan ${ }^{17}$. Dari 42 orang dengan intensitas ringan, sebanyak $33(78,57 \%)$ mengalami obesitas.
Banyaknya responden yang telah berusia lanjut juga menjadi salah satu alasan tingginya responden dengan intensitas ringan. Sebanyak 27 $(64,29 \%)$ responden usia $\geq 60$ tahun memiliki aktivitas dengan intensitas ringan. Pada lanjut usia, terdapat penurunan massa otot, perubahan distribusi darah ke otot, penurunan $\mathrm{PH}$ dalam sel otot, otot menjadi lebih kaku, dan ada penurunan kekuatan $\operatorname{otot}^{27}$. Oleh karenanya, lansia memiliki aktivitas yang terbatas. Kebanyakan mereka hanya memiliki aktivitas sedentari seperti duduk, berbaring, menonton tv, dan bermain dengan cucu. Ini terbukti dari kuesioner P16 yaitu, sebesar $47(48,45 \%)$ responden memiliki aktivitas sedentari $3-6$ jam terdiri dan sebesar $11(11,34 \%)$ responden memiliki aktivitas sedentari > 6 jam. Perilaku sedentari merupakan perilaku berisiko terhadap salah satu terjadinya penyakit penyumbatan pembuluh darah, penyakit jantung dan bahkan mempengaruhi umur harapan hidup ${ }^{11}$.

Selain itu, responden pada penelitian ini lebih gemar menggunakan alat transportasi dibanding melakukan jalan kaki atau bersepeda, terbukti pada kuesioner domain transportasi (P7) dari 97 responden hanya sebesar $38(39,18 \%)$ responden yang berjalan kaki lebih dari 10 menit. Padahal penelitian di Indiana University dalam Journal of hypertension edisi September 2006, membuktikan bahwa berjalan kaki empat kali 10 menit setiap hari akan menurunkan tekanan darah sebanyak 6,6 poin pada tekanan darah $\geq 120 / \geq 80 \mathrm{mmHg}$ dan 12,9 poin pada tekanan darah $\geq 140 / \geq 90 \mathrm{mmHg}^{8}$. Selain itu, melakukan aktivitas fisik aerobik seperti jalan kaki 30 menit/hari dapat menurunkan tekanan darah 4 $9 \mathrm{mmHg}^{6}$. Mengemudikan kendaraan seperti mengendarai motor atau mengendarai mobil merupakan aktivitas dengan intensitas ringan. Kurang aktivitas fisik menjadikan daya pompa jantung kurang optimal sehingga aliran darah dalam tubuh tidak lancar ${ }^{15}$.

Aktivitas fisik yang berisiko mempengaruhi peningkatan tekanan darah 
adalah aktivitas fisik dengan intensitas ringan atau tidak tercukupi. Ini sesuai dengan penelitian yang dilakukan oleh Muliyati yang menunjukkan bahwa kurang aktivitas fisik berisiko hipertensi 1.1 kali dibandingkan dengan cukup aktivitas fisik $^{25}$. Didukung pula oleh hasil penelitian Atun dkk yang menyatakan subyek dengan aktivitas fisik kurang mempunyai risiko 4.9 kali terkena hipertensi dibandingkan dengan subyek yang memiliki aktivitas fisik sedang. Seseorang dengan aktivitas fisik kurang, memiliki kecenderungan 30 - 50 persen terkena hipertensi daripada mereka yang aktif ${ }^{10}$.

Aktivitas fisik yang tidak cukup merupakan salah satu faktor risiko utama kematian global dan terus meningkat di banyak negara, menambah beban penyakit tidak menular seperti hipertensi dan mempengaruhi general kesehatan di seluruh dunia. Orang yang kurang aktif memiliki $20 \%$ sampai $30 \%$ peningkatan risiko kematian dibandingkan orang yang cukup aktif. Melakukan aktivitas fisik reguler dengan intensitas sedang, seperti berjalan kaki, bersepeda, atau berolahraga, memiliki manfaat yang signifikan bagi kesehatan ${ }^{23}$. Diharapkan masyarakat turut aktif dalam memanfaatkan fasilitas olahraga yang telah tersedia untuk meningkatkan intensitas aktivitas fisik sebagai bentuk pencegahan tekanan darah tinggi.

\section{KESIMPULAN DAN SARAN KESIMPULAN}

Kesimpulan yang didapatkan dalam penelitian ini sebagai berikut:

1. Karakteristik responden di Puskesmas Rawasari Kota Jambi adalah sebagai berikut; paling banyak responden berusia $60-69$ tahun sebanyak 40 orang atau sebesar 41,24\%, responden terbanyak adalah laki-laki yaitu sebanyak 50 orang atau sebesar 51,55\%, dengan tingkat pendidikan lebih banyak yang tamat SMA/MA yaitu sebanyak 43 orang atau sebesar 44,33\%, dan pekerjaan responden yang paling banyak adalah ibu rumah tangga yaitu sebanyak 37 orang atau sebesar 38,4\%.

2. Responden yang memiliki obesitas di Puskesmas Rawasari Kota Jambi Tahun 2018 yaitu sebanyak 52 orang atau sebesar 53,61\%.

3. Responden memiliki aktivitas fisik dengan intensitas ringan yaitu sebanyak 42 orang atau sebesar 43,39\%.

4. Responden di Puskesmas Rawasari Kota Jambi Tahun 2018 yang memiliki hipertensi adalah sebanyak 61 orang atau sebesar $62,89 \%$.

5. Ada hubungan yang signifikan antara obesitas dengan kejadian hipertensi di Puskesmas Rawasari Kota Jambi Tahun 2018 dengan nilai $p$ value $=0,004$.

6. Ada hubungan yang signifikan antara aktivitas fisik dengan kejadian hipertensi di Puskesmas Rawasari Kota Jambi Tahun 2018 dengan nilai $p$ value $=0,000$.

\section{SARAN}

Adapun saran yang dapat diberikan yaitu,

1. Meningkatkan kesadaran masyarakat melalui kegiatan posbindu dan prolanis berupa tenaga kesehatan yang aktif melakukan kunjungan ke rumah (home visit) dan SMS pengingat jadwal konsultasi ke Puskesmas dalam pemantauan kesehatan dan kegiatan senam prolanis.

2. Meningkatkan kegiatan perubahan Perilaku Hidup Bersih dan Sehat (PHBS) yang difokuskan pada Gerakan Masyarakat Hidup Sehat (GERMAS) minimal implementasi melalui; melakukan aktivitas fisik 30 menit per hari, deteksi dini penyakit tidak menular, makan buah dan sayur, dan memeriksa kesehatan secara rutin.

3. Pemerintah daerah menyediakan fasilitas yang mendukung, seperti alat olahraga di tempat-tempat umum dalam bentuk meningkatkan intensitas aktivitas fisik untuk pencegahan tekanan darah tinggi.

4. Diharapkan masyarakat meningkatkan kesadaran dan peduli terhadap kesehatan diri 
sendiri untuk terus mengontrol tekanan darah serta lebih mengerti terhadap faktor - faktor yang dapat meningkatkan tekanan darah.

5. Masyarakat dapat mengadopsi modifikasi gaya hidup sesuai rekomendasi dari JNC VII antara lain, menurunkan berat badan hingga tercapai nilai IMT normal (18,5 - 24,9); mengadopsi pola makan DASH (Dietary Approach to Stop Hypertension) diet kaya dengan buah, sayur, dan rendah lemak; diet rendah sodium $(\leq 2,4$ gram natrium atau 6 gram $\mathrm{NaCl}$ ); melakukan aktivitas fisik aerobik seperti jalan kaki 30 menit/hari; dan mengurangi konsumsi alkohol.

\section{DAFTAR PUSTAKA}

1. Bustan, M N., 2007. Epidemiologi Penyakit Tidak Menular. Edisi ke-2. Jakarta: PT. Rineka Cipta

2. Masriadi., 2016. Epidemiologi Penyakit Tidak Menular. Edisi ke-1. Jakarta: CV Trans Info Media

3. World Health Organization (WHO), 2017. Noncommunicable Diseases. (online). Diunduh dari: http://www.who.int/ (diakses 20 Nov 2017).

4. World Health Organization (WHO), 2015. Q\&As on Hypertension (online). Diunduh dari: http://www.who.int/ (diakses 20 Agt 2017).

5. World Health Organization (WHO)., 2016. Bulletin of the World Health Organization (online). Diunduh dari: http://www.who.int/bulletin/ (diakses 02 Sep 2017).

6. Depkes RI., 2006. Pharmaceutical Care Untuk Penyakit Hipertensi. Edisi ke-1. Jakarta: Depkes RI

7. Kumar V., Abbas AK., Fausto N. 2005. Hypertensive Vascular Disease. Dalam: Robin and Cotran Pathologic Basis of Disease. Edisi ke-7. Philadelphia: Elsevier Saunders .p 528-529

8. Nurrahmani U. 2012. Stop Hipertensi. Edisi ke1. Yogyakarta: Familia

9. Sulastri D, Elmatris, Ramadhani R., 2012. Hubungan Obesitas dengan Kejadian Hipertensi pada Masyarakat Etnik Minangkabau di Kota
Padang. (diakses 04 Sep 2017); 36(2):(14 layar). Diunduh dari URL: http://jurnalmka.fk.unand.ac.id/

10. Atun L, Siswati T, Kurdanti W., 2014. Asupan Sumber Natrium, Rasio Kalium natrium, Aktifitas Fisik, dan Tekanan Darah Pasien Hipertensi. (diakses 05 Sep 2017); 6(1):63-71. Diunduh dari URL: http://ejournal.litbang.depkes.go.id/

11. Kementrian RI., 2013. Riset Kesehatan Dasar (Riskesdas) 2013. Diunduh dari: http://www.depkes.go.id/ (diakses 05 Juli 2017)

12. Dinas Kesehatan Kota Jambi., 2015. Laporan Tahunan Kejadian Hipertensi di Puskesmas Kota Jambi Tahun 2015. Jambi

13. Dinas Kesehatan Kota Jambi., 2016. Laporan Tahunan Kejadian Hipertensi di Puskesmas Kota Jambi Tahun 2016. Jambi

14. Hasdianah H R, Siyoto S, Peristyowati Y., 2014. Pemanfaatan Gizi, Diet, dan Obesitas. Edisi ke1. Yogyakarta: Nuha Medika

15. Oktaliani R., 2017. Hubungan Gaya Hidup Dengan Kejadian Hipertensi Pada Lansia di Puskesmas Simpang IV Sipin Kota Jambi Tahun 2017.

16. Rohkuswara T D, Syarif S., 2017. Hubungan Obesitas Dengan Kejadian Hipertensi Derajat 1 di Pos Pembinaan Terpadu Penyakit Tidak Menular (Posbindu PTM) Kantor Kesehatan Pelabuhan Bandung Tahun 2016. (diakses 15 Mei 2018); 1(2):13-18. Diunduh dari URL: http://journal.fkm.ui.ac.id/

17. Anggara F H D, Prayitno N., 2013. FaktorFaktor Yang Berhubungan Dengan Tekanan Darah Di Puskesmas Telaga Murni, Cikarang Barat Tahun 2012. (diakses 29 Juni 2018); 5(1):20-25. Diunduh dari URL: http://fmipa.umri.ac.id/

18. Hasanah M, dkk., 2016. Hubungan Obesitas Dengan Hipertensi Pada Masyarakat Di Wilayah RW 13 Dusun Mojosari Desa Ngenep Kecamatan Karangploso. (diakses 04 Juni 2018); 1(2):35-44. Diunduh dari URL: https://publikasi.unitri.ac.id/

19. Novitasary M D, Mayulu N, Kawengian S E S., 2013. Hubungan Antara Aktivitas Fisik dengan Obesitas pada Wanita Usia Subur Peserta Jamkesmas di Puskesmas Wawonasa 
Kecamatan Singkil Manado. (diakses 10 Juli 2018); 1 (2) 1040 - 1046. Diunduh dari URL: https://ejournal.unsrat.ac.id/

20. Widiantini W, Tafal Z., 2014. Aktivitas Fisik, Stres, dan Obesitas pada Pegawai egeri Sipil. (diakses 10 Juli 2018); 8(7): 330 - 336. Diunduh dari URL: http://journal.fkm.ui.ac.id/

21. Korneliani K, Meida D., 2012. Obesitas dan Stress dengan Kejadian Hipertensi. (diakses 26 Mei 2018); 7(2):117-121. Diunduh dari URL: http://journal.unnes.ac.id

22. Situmorang P R., 2015. Faktor-Faktor Yang Berhubungan dengan Kejadian Hipertensi Pada Penderita Rawat Inap di Rumah Sakit Umum Sari Mutiara Medan Tahun 2014. (diakses 21 Mei 2018); 1(1):67-72. Diunduh dari URL: http://ejournalhealth.com/

23. World Health Organization (WHO)., 2017. Global Strategy on Diet, Physical Activity and Health. (online). Diunduh dari: http://www.who.int/ (diakses 12 Nov 2017).

24. Hengli., 2013. Hubungan Antara Merokok Dan Aktivitas Fisik Dengan Kejadian Hipertensi Pada Pria Di Wilayah Kerja Puskemas Siantan Hulu Kecamatan Pontianak Utara. (diakses 06 Juni 2018). Diunduh dari URL: http://jurnal.untan.ac.id/

25. Muliyati H, Syam A, Sirajuddin S., 2011. Hubungan Pola Konsumsi Natrium dan Kalium Serta Aktivitas Fisik dengan Kejadian Hipertensi pada Pasien Rawat Jalan di RSUP Dr.Wahidin Sudirohusodo Makassar. (diakses 25 Mei 2018); 1(1) 46-51. Diunduh dari URL: http://download.portalgaruda.org/article.

26. Garnadi Y., 2012. Hidup Nyaman Dengan Hipertensi. Edisi ke-1. Jakarta: AgroMedia Pustaka

27. Ambardini R L., 2009. Aktivitas Fisik Pada Lanjut Usia. (diakses 12 Juli 2018). Diunduh dari: http://staffnew.uny.ac.id/ 